\title{
Influence of Marker Genes on Physicochemical Properties of Starch Produced by Transgenic Cassava (Manihot esculenta Crantz) Plants
}

\author{
Jelili T. Opabode ${ }^{1}$, John A. Akinkunmi ${ }^{2} \&$ Oluyemisi A. Akinyemiju ${ }^{1}$ \\ ${ }^{1}$ Department of Crop Production and Protection, Obafemi Awolowo University, Ile-Ife, Nigeria \\ ${ }^{2}$ Roots and Tubers Improvement Programme, International Institute of Tropical Agriculture, Ibadan, Nigeria \\ ${ }^{3}$ Department of Agricultural extension and Rural Sociology, Obafemi Awolowo University, Ile-Ife, Nigeria \\ Correspondence: Jelili T. Opabode, Department of Crop Production and Protection, Obafemi Awolowo University, \\ Ile-Ife, Nigeria. E-mail: jopabode@yahoo.com
}

Received: June 13, 2012 Accepted: July 27, 2012 Online Published: December 13, 2012

doi:10.5539/jas.v5n1p201 URL: http://dx.doi.org/10.5539/jas.v5n1p201

\begin{abstract}
The study monitored the influence of genetic modification of cassava plants with NPT-II and GUS genes on starch content and physicochemical properties of transgenic starch for three cycles of vegetative propagation from 2010-2012. There were no significant ( $p>0.05$ ) differences in the starch content and physicochemical properties among the three cycles of vegetative propagation. The NPT-II and GUS genes were strongly expressed in the vascular bundle, starch synthesizing and storage cells. The type of TME 12 variety (transgenic vs non-transgenic) has significant $(\mathrm{p}<0.05)$ influence on starch content, crude fibre, pasting viscosity and breakdown value. Starch content and crude fibre of non-transgenic plant $(83.9 \%, 3.6 \%)$ were significantly $(p<0.05)$ higher than that of transgenic plant $(77.5 \%, 2.9 \%)$. Similarly, pasting viscosity and breakdown value (783.2 mPa s, $284.2 \mathrm{mPa} \mathrm{s})$ of non-transgenic plants were greater than that of transgenic plant $(621.0 \mathrm{mPa} \mathrm{s}, 133.1 \mathrm{mPa}$ s) significantly. The implications of the findings on future genetic modification of cassava with NPT-II and GUS genes for starch quality improvement are discussed.
\end{abstract}

Keywords: marker genes, cassava, transgenic, starch, physicochemical properties

Abbreviations: GUS: $\beta$-glucuronidase, NPT-II: Neomycin phosphotransferase-II

\section{Introduction}

Cassava is a root crop and constitutes an important source of energy in the diet of 600 million people in tropical and subtropical countries (Defloor et al., 1998). The starch content of cassava roots ranges from $65-91 \%$ of its total root dry weight depending on the cultivar (Sanchez et al., 2009). Like starches from other plants, cassava starch can be fractionated into two types of polymers namely: amylose and amylopectin. The proportion of amylose to amylopectin in starch determines the physical, chemical and functional properties of cassava starch. There is considerable interest in generating plants with altered starch characteristics in a range of species, including potato and maize, for industrial applications and human health (Davis et al., 2003). For example, Amflora, a genetically modified potato variety capable of producing waxy starch for industrial applications has recently been approved for commercial cultivation by European Commission (Benner, 2010). Similarly, the modification of starch properties in cassava would offer new industrial applications for this important root crop. For example, creation of cassava variety that produces low-amylose (waxy) starch would take advantage of existing huge market in global food industry for low-amylose starches which is estimated to be US\$10 million (Blennow, 2003).

Conventional breeding of cassava is challenging due to the highly heterozygous nature of the crop which is preventing a backcross scheme, exacerbated by poor flowering and limited seed set of many varieties (Ceballos et al., 2004). Many genes are involved in starch biosynthesis and there is limited natural variation with regards to starch metabolism in cassava compared to other crops such as maize. To date, only two starch mutants have been reported in cassava: a natural mutation in a granule-bound starch synthase gene resulting in production of amylose-free starch and a gamma irradiation-induced mutation in an isoamylase gene resulting in high-amylose starch (Ceballos et al., 2007; Ceballos et al., 2008). Because most mutations affecting starch metabolism are recessive, moving useful genetic variants into the appropriate background via conventional breeding is arduous. 
In the field, cassava is typically propagated clonally by stem cuttings. This propagation strategy is ideal for improvement through crop bio-engineering as gene segregation through outcrossing is limited (Taylor et al., 2004). Several transgenic cassava varieties have been developed to address numerous abiotic and biotic constraints militating against the crop production. For examples, cyanogenic glucosides-free, mosaic resistant and enhanced starch quantity and protein-rich cassava varieties have been produced by transgenic approach (Zhang et al., 2003, Jorgensen et al., 2005, Zhang et al., 2005, Ihemere et al., 2006). However, modification of cassava starch properties by transgenic approach has attracted limited research attention. So far the only reported transgenic cassava plants with enhanced starch properties are the ones producing amylose-free starch by antisense inhibition of granule-bound starch synthase I (Raemakers et al., 2005) and enhanced quantity of starch (Ihemere et al., 2006). The genetically modified cassava plants are wild-type and varieties which are not cultivated by African farmers. In fact, no cassava variety grown in Africa has been genetically modified by transgenic approach for enhanced starch properties. It was against this background that we set up Cassava Improvement Programme to create low-amylose cassava variety preferred by African farmers and consumers such as TME 12.

To date, genetic transformation of cassava is accomplished in two broad stages: manipulation with genetic markers and transformation with desired agronomic traits (Zhang \& Pounti-Kaerlas 2004; Hankoua et al., 2006). Selectable and screenable markers such as NPT-II and GUS, respectively are co-transformed into cassava tissue to serve different and important purposes. The NPT-II marker allows the selection of transformed cells or tissue explant by their ability to grow in the presence of an antibiotic (Gonzalez et al., 1998, Zhang \& Pounti-Kaerlas 2004). In addition, they are used to follow the inheritance of foreign genes in a segregrating population of transgenic cassava plants. The GUS marker gene is included in many transformation vectors for two reasons: to confirm the transformed status of tissues growing on media continuing selective antibiotics and to identify transformants in conditions where transformation frequencies are high (Hankoua et al., 2006). Furthermore GUS marker is used to know the temporal and spatial expression pattern of the foreign gene (Schreuder et al., 2001). Transgenic crops that contain NPT-II and GUS in their T-DNA vector in addition to agronomic traits have been reported to display slower growth than the non-transgenic ones (Vinocur \& Altman, 2005). Similarly, Lecardonnel et al., (2004) reported that genetic transformation of potato with NPT-II -GUS marker genes enhances foliage consumption by Colorado potato beetle larvae. This present study examined TME 12-2010 which is a transgenic cassava plant containing a transformation vector which carried NPT-II and GUS genes as selectable and screenable markers, respectively. In the present communication, the starches produced by the $1^{\text {st }}, 2^{\text {nd }}$ and $3^{\text {rd }}$ cycles of vegetative propagation of transgenic cassava TME 12-2010 were subjected to proximate and physicochemical analyses and compare with starch from non-transgenic TME 12 plants.

\section{Material and Methods}

\subsection{Plant Material and Growth Condition}

Stem cuttings of NPT-II and GUS genes genetically modified TME 12-2010 and TME 12 plants were grown in plastic pots containing $12 \mathrm{~kg}$ rich soil at Central Biotechnology Laboratory, International Institute of Tropical Africa (IITA), Ibadan containment facilities. The soil chemical properties were: $\mathrm{pH} 7.0$, organic carbon $0.92 \%$, total nitrogen $0.1 \%$, available Phosphorus $3.3 \%$, cation exchange capacity $15.24 \mathrm{meq} / 100 \mathrm{~g}$ and sandy loam textural class. Details of how the genetically modified cassava plant, TME 12-2010, was produced can be found in Opabode (2010). Plants were watered daily and manually to $80 \%$ moisture content. Tubers were harvested when plants were 10 months old. The study was conducted for three cycles using cuttings as planting materials.

\subsection{DNA Extraction and PCR Amplification of GUS and NPT-II Genes}

To confirm the presence of GUS and NPT-II genes in the transgenic cassava plant, TME 12-2010, DNA was extracted from young leaves $(0.5-1.0 \mathrm{~g})$ of the plants in the first, second and third vegetative propagations by Dellarporta et al., (1983). DNA was resuspended at a concentration of $500 \mathrm{ng} / \mu \mathrm{l}$. The quality of the DNA was verified by running $2 \mu \mathrm{l}$ of the DNA alongside a molecular weight marker $\lambda$ Pst I on $0.8 \%$ agarose gel in $1 \mathrm{x} \mathrm{TAE}$ (Tris Acetate EDTA) buffer at 500 volts for one hour. Amplification of GUS and NPT-II gene were conducted with primer specific for GUS and NPT-II. Each amplification was each out in $10 \mu$ l-reaction volume, composed of $1 \mu \mathrm{l}$ of $10 \mathrm{x}$ buffer, $0.5 \mu \mathrm{l}$ of $\mathrm{MgCl}_{2}(25 \mathrm{mM}), 1 \mu \mathrm{l}$ each of primer $\mathrm{F}$ and $\mathrm{R}(1 \mu \mathrm{M}), 0.5 \mu \mathrm{l}$ of dNTPs $(2.5 \mathrm{mM}), 1 \mu \mathrm{l}$ template DNA (500 ng), $4.8 \mu \mathrm{l} \mathrm{H}_{2} \mathrm{O}$ and $0.2 \mu \mathrm{l}$ of Taq DNA polymerase (5 U) (Bioline Inc.,USA). The PCR amplification profile consisted of initial denaturation at $94^{\circ} \mathrm{C}$ for one minute and 30 cycles of amplification $\left(94{ }^{\circ} \mathrm{C}\right.$ for 30 seconds, $55^{\circ} \mathrm{C}$ for 30 seconds, $72^{\circ} \mathrm{C}$ for 45 seconds) with a final cycle of 5 minutes at $72^{\circ} \mathrm{C}$. All PCR amplifications were carried out in a Peltier thermal cycler (PTC 2000, MJ Research, India). For each PCR experiment, amplification (PCR) products were separated alongside a molecular weight marker (11.0 kb plus pst 1 lambda DNA) by $0.8 \%$ agarose gel electrophoresis in $1 \times$ TAE (Tris acetate EDTA) buffer ran at 500 volts for one 
hour. The gel was stained with $1 \%$ ethidium bromide for 30 seconds before washing for 45 secs and visualized under UV light. Gel photographs were scanned through a Gel Doc System (Gel Doc. 2000, BioRad, California, USA).

\subsection{Histochemical GUS Assay}

To know the expression pattern of the GUS marker gene, histochemical localization of GUS activity in a mature tuber from each of the three propagations of the transgenic plants was carried out essentially as described by Jefferson et al., (1987). Plant material was incubated in a GUS assay buffer [10 $\mathrm{Mm} \mathrm{Na}_{2} \mathrm{EDTA}_{2} \mathrm{H}_{2} 0,0.1 \%$ Triton $\mathrm{X}-100,0.3 \%$ 5-bromo-4-chloro-3-indolyl $\beta$-D-glucuronide (X-Gluc), $\left.0.1 \mathrm{M} \mathrm{NaH}_{2} \mathrm{P0}_{4}, 0.5 \mathrm{M} \mathrm{K}_{3} \mathrm{Fe}(\mathrm{CN})_{6}\right]$. After 2-6 h incubation at $37^{\circ} \mathrm{C}$, the tissues were cleared with repeated $70 \%$ ethanol washes and stored in $70 \%$ ethanol. Some tissues were sectioned by hand and visualized in a Stemi 2000 Zeiss stereomicroscope. The NPT-II ELISA method was used to confirm the presence NPT-II gene. Details of the procedure are provided in Opabode (2010).

\subsection{Root Dry Matter Content}

The method of Joslyn (1970) was used for the determination of dry matter content. Five roots were cut into small pieces and mixed. Dry matter was determined after drying $50 \mathrm{~g}$ of freshly cut sample at $60^{\circ} \mathrm{C}$ for 48 hours.

$$
\% \text { Root dry matter }=\frac{W 3-W 1}{W 2-W 1} \times 100
$$

Where: $\mathrm{W}_{1}=$ Weight of crucible, $\mathrm{W}_{2}=$ Weight of crucible + sample before drying, $\mathrm{W}_{3}=$ Weight of crucible + sample after drying.

\subsection{Sugars and Starch Content}

The method described by Dubois et al., (1956) was used for the determination of sugar and starch content. This involves weighing $0.020 \mathrm{~g}$ finely ground sample into centrifuge tubes and wetted with $1 \mathrm{ml}$ of ethanol. Two ml of distilled water was added, followed by $10 \mathrm{ml}$ hot ethanol. The mixture was vortexed and centrifuged using Sorvall centrifuge model GLC-1 (Newtown, Conneticut, USA) at 10,000 x g for ten minutes. The supernatant was collected and used for free sugar analysis, while the residue was used for starch analysis. To the residue was added $7.5 \mathrm{ml}$ of perchloric acid and allowed to hydrolyze for 1 hour. It was diluted to $25 \mathrm{ml}$ with distilled water and filtered through whatman no 2 filter papers. From the filtrate $0.05 \mathrm{ml}$ was taken, made up to $1 \mathrm{ml}$ with distilled water, vortexed and ready for color development as was described for standard glucose curve preparation. From the supernatant made up to $20 \mathrm{ml}$ with distilled water, an aliquot of $0.2 \mathrm{ml}$ was taken. $0.5 \mathrm{ml}(5 \%$ phenol) and $2.5 \mathrm{ml}$ concentrated sulphuric acid was added. The sample was allowed to cool and the absorbance read on a spectrophotometer (Milton Roy Company, USA), model spectronic 601 at $490 \mathrm{~nm}$ wavelength.

$$
\% \text { Sugar }=\frac{\text { Abs }- \text { Intercept } \times \text { Dilution factor } \times \text { Volume }}{\text { Weight of sample } \times \text { Slope } \times 10,000}
$$

Where: Abs. $=$ Absorbance; Dilution factor $=5$; Volume $=20$; Slope $=0.0055$, and

Intercept $=0.0044$

$$
\% \text { Starch }=\frac{\text { Abs }- \text { Intercept } \times \text { Dilution factor } \times \text { Volume } \times 0.9}{\text { Weight of sample } \times \text { Slope } \times 10,000}
$$

Where: Abs. $=$ Absorbance; Dilution factor $=20 ;$ Volume $=25 ;$ Slope $=0.0055$, and

Intercept $=0.0044$

\subsection{Amylose content}

Amylose content was determined using the method of Williams et al., (1970) which involved the preparation of stock iodine solution and iodine reagent. First $0.1 \mathrm{~g}(100 \mathrm{mg})$ of the samples was weighed into a $100 \mathrm{ml}$ volumetric flask, thereafter $1 \mathrm{ml}$ of $99.7-100 \%(\mathrm{v} / \mathrm{v})$ ethanol and $9 \mathrm{ml} 1 \mathrm{~N}$ sodium hydroxide $(\mathrm{NaOH})$ were carefully added. The mouth of the flask was covered with parafilm or foil and the contents were mixed well. The samples were heated for 10 minutes in a boiling water bath to gelatinize the starch (the timing was started when boiling began). The samples were removed from the water bath and allowed to cool very well, then made up to the mark with distilled water and shaken thoroughly. Next, $5 \mathrm{ml}$ was pipetted into another $100 \mathrm{ml}$ volumetric flask and $1.0 \mathrm{ml}$ of $1 \mathrm{~N}$ acetic acid and $2.0 \mathrm{ml}$ of iodine solution were added. The flask was topped up to the mark with distilled water. Absorbance (A) was read using a Spectrophotometer at $620 \mathrm{~nm}$ wavelength. The blank contained $1 \mathrm{ml}$ of ethanol, 9 $\mathrm{ml}$ of sodium hydroxide, boiled and topped up to the mark with distilled water. Finally, $5 \mathrm{ml}$ was pipetted into a 
$100 \mathrm{ml}$ volumetric flask, $1 \mathrm{ml}$ of $1 \mathrm{~N}$ acetic acid and $2 \mathrm{ml}$ of iodine solution were added and topped up to the mark. This was used to standardize the spectrophotometer at $620 \mathrm{~nm}$.

The amylose content was calculated as: Amylose content $(\%)=3.06 \times \mathrm{A} \times 20$

Where: $\mathrm{A}=$ Absorbance value

\subsection{Paste Clarity}

The methodology described by Craig et al., (1989) was used. A 1\% (db) aqueous dispersion of starch was boiled at $97^{\circ} \mathrm{C}$ (1000 $\mathrm{m}$ above sea level) with shaking thoroughly every $5 \mathrm{~min}$ for $30 \mathrm{~min}$. Transmittance was measured after cooling to room temperature at $650 \mathrm{~nm}$.

\subsection{Pasting Properties}

Pasting properties were determined as described by Craig et al., (1989). Hot starch dispersion viscosity profiles were obtained with a Rapid Visco Analyser model RVA-4 Series (Newport Scientific, Warriewood, Australia). Starch $(1.25 \mathrm{~g}, \mathrm{db})$ was dispersed in distilled water (about $23 \mathrm{~cm}^{3}$ ) to yield a $5 \%$ suspension. Viscosity was recorded using the temperature profile: holding at $50^{\circ} \mathrm{C}$ for $1 \mathrm{~min}$, heating from $50^{\circ} \mathrm{C}$ to $90^{\circ} \mathrm{C}$ at $67^{\circ} \mathrm{C} / \mathrm{min}$, holding at $90^{\circ} \mathrm{C}$ for $5 \mathrm{~min}$, and then cooling down to $50^{\circ} \mathrm{C}$ at $67^{\circ} \mathrm{C} / \mathrm{min}$ with continuous stirring at $160 \mathrm{rpm}$. Two parameters were measured: pasting temperature (PT) and peak viscosity (PV). With them, three additional parameters were calculated: breakdown (BD), setback (SB), and consistency (CS).

\subsection{Swelling Power and Solubility}

Swelling power and solubility of starch was determined by the method of Sanchez et al., (2009) method. Swelling power and solubility were determined using $1.5 \%(\mathrm{w} / \mathrm{w}, \mathrm{db})$ starch dispersions $(0.42 \mathrm{~g}$ dry matter dispersed in $27.58 \mathrm{~g}$ distilled water). The paste was prepared in a Rapid Visco Analyser (RVA) holding at $35^{\circ} \mathrm{C}$ for $1 \mathrm{~min}$, heating to $75^{\circ} \mathrm{C}$ (complete gelatinization of starch) at $67^{\circ} \mathrm{C} / \mathrm{min}$, holding at $75^{\circ} \mathrm{C}$ for $2.5 \mathrm{~min}$. The paste was immediately transferred to a $50 \mathrm{~cm} 3$ centrifuge tube. The supernatant and sediment after centrifugation for $5 \mathrm{~min}$ at $6000 \times \mathrm{g}$ at $25^{\circ} \mathrm{C}$ were collected and weighed (Wsu and Wse, respectively) then dried at $100^{\circ} \mathrm{C}$ for $24 \mathrm{~h}$ and $48 \mathrm{~h}$ respectively and weighed ( $D$ su and $D$ se, respectively). Two parameters were calculated: concentration of soluble material in the supernatant (solubility) and the swelling power.

Solubility $(\% \mathrm{db})=100 \times \mathrm{Dsu} / 0.42$

Swelling power $=(W$ se $-D$ se $) / D$ se. Factor 27.86 is calculated as total volume $(\mathrm{cm} 3)$ of the paste.

\subsubsection{Ash Content}

This was done using AOAC (2000) method, which involved weighing $2 \mathrm{~g}$ of the samples into a crucible, which had been previously ignited and weighed. The crucible containing the sample was then placed on a hot plate inside the fume cupboard to char the organic matter. The remaining residue (inorganic matter) was transferred into the muffle furnace (Fisher Scientific Co. USA), model 186A maintained at $600{ }^{\circ} \mathrm{C}$ for 6 hours to ash the samples completely. The crucibles were transferred into desiccators to cool and were weighed.

$$
\% \text { Ash content }=\frac{W 3-W 1}{W 2-W 1} \times 100
$$

Where: $\mathrm{W}_{1}=$ Weight of crucible, $\mathrm{W}_{2}=$ Weight of crucible + sample before ashing, $\mathrm{W}_{3}=$ Weight of crucible + sample after ashing.

\subsubsection{Crude Fiber Content}

The fiber content was determined as described by Sanchez et al., (2009) as the loss on ignition of dried residue remaining after digestion of cassava flour $(2 \mathrm{~g})$ with $1.25 \% \mathrm{H}_{2} \mathrm{SO} 4$ and $1.25 \% \mathrm{NaOH}$.

$$
\% \text { Crude fibre content }=\frac{W 3-W 1}{W 2-W 1} \times 100
$$

Where: $\mathrm{W}_{1}=$ Weight of crucible, $\mathrm{W}_{2}=$ Weight of crucible + sample before digestion. $\mathrm{W}_{3}=$ Weight of crucible + sample after digestion.

\section{Results}

The PCR amplification of DNA of transgenic plants confirmed the presence of GUS and NPT-II genes in the plants (Figure 1). The GUS expressions in mature tubers were similar in the three cycles of propagation of transgenic plants. Cross-sections from different regions of a mature tuber were examined for pCsVMV-GUS expression: GUS activities were similar in all the tuber regions with uniform expression in the vascular tissues 
including vascular parenchyma, which is the major site for starch accumulation and storage, and in the external phloem. pCsVMV-GUS was strongly expressed in the cortical cells (Figure 2).

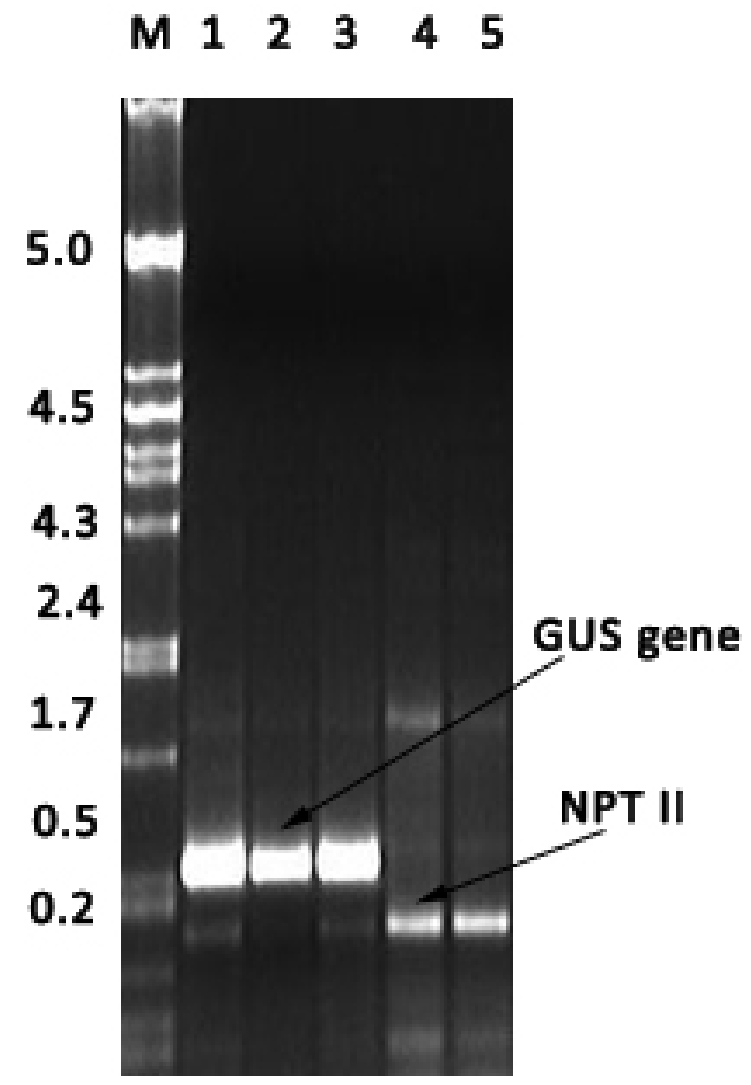

Figure 1. Amplification of GUS and NPT-II gene in TME 12-2010. M=DNA marker, 1, 2 \& 3=GUS gene amplifications at $1^{\text {st }}, 2^{\text {nd }}$ and 3 rd cycle of propagation, $4 \& 5=$ NPT II gene amplifications at 1 st and 2 nd cycle of propagation. The $3^{\text {rd }}$ NPT II gene amplification was contaminated and discarded
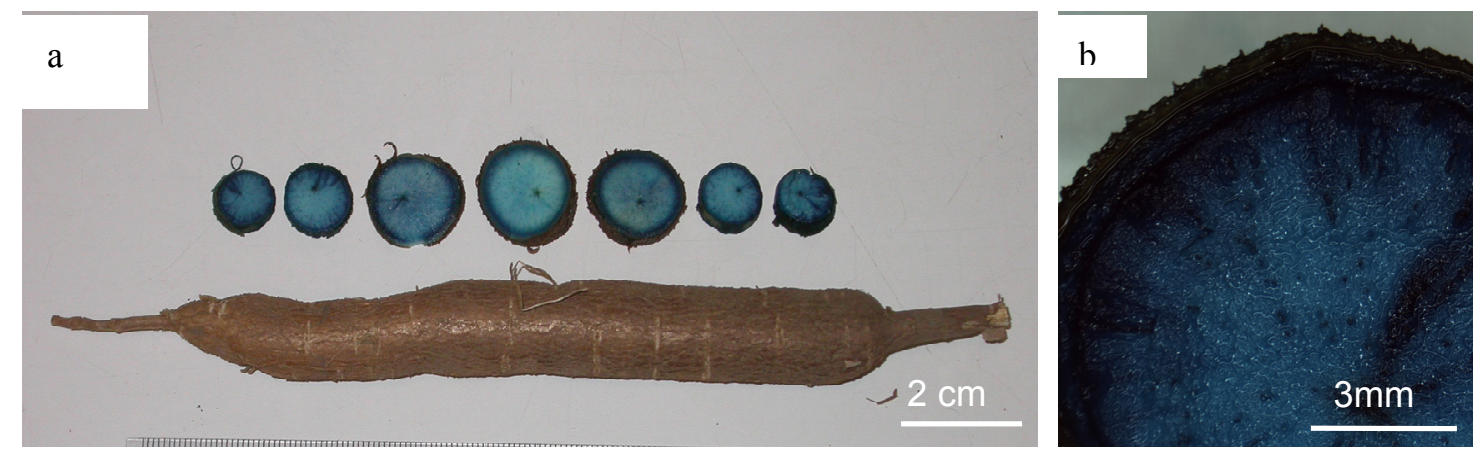

Figure 2. Histochemical localization of GUS activity in various region of mature tuber from transgenic cassava plant, TME 12-2010. a. cross-sections of different regions of mature tuber showing uniform GUS expression in vascular bundle. B. close-up cross section of mature tuber showing stronger expression in the cortex with uniformed expression in the vascular tissues

The type of TME 12 variety (transgenic vs non-transgenic) has significant $(p<0.05)$ influence on starch content, crude fibre, pasting viscosity and breakdown value (Table 1$)$. Starch content had the least variation $\quad(\mathrm{cv}=21.2 \%$ : $\mathrm{R}=0.71 \%$ ) among all the parameters measured.. However, the type of TME 12 variety has no significant influence on dry matter, ash, total sugar pasting clarity, pasting temperature, consistency solubility and swelling power. Tuber size has no significant effect on all the parameter measured. The interaction of TME 12 type and tuber size on all the parameters measured was not significant (Table 1). Starch content and crude fibre of non-tarnsgenic 
$(83.9 \%, 3.6 \%)$ were significantly $(\mathrm{p}<0.05)$ higher than that of transgenic plant $(77.5 \%, 2.9 \%)$ (Table 2$)$. Similarly, pasting viscosity and breakdown value (783.2 mPas, $284.2 \mathrm{mPas})$ of non-transgenic plants were greater than that of transgenic plant (621.0 mPas, $133.1 \mathrm{mPas}$ ) significantly.

Table 1. Analysis of variance of proximate analysis and physicochemical properties of transgenic starch as affected by TME 12 type and tuber size

\begin{tabular}{lccccc}
\hline Properties & $\begin{array}{c}\text { TME12 TYPE } \\
(\mathrm{A})\end{array}$ & $\begin{array}{c}\text { TUBER SIZE } \\
(\mathrm{B})\end{array}$ & $\begin{array}{c}\text { A X B } \\
\text { INTERACTION }\end{array}$ & $\mathrm{R}^{2}$ & CV (\%) \\
\hline Dry matter & 0.082 & 0.078 & 0.721 & 0.32 & 42.1 \\
Starch content & $0.032^{*}$ & 0.327 & 0.521 & 0.71 & 21.2 \\
Ash & 0.064 & 0.078 & 0.632 & 0.41 & 43.8 \\
Crude fibre & $0.042^{*}$ & 0.064 & 0.792 & 0.53 & 51.1 \\
Total sugar & 0.081 & 0.632 & 0.840 & 0.35 & 60.7 \\
Pasting calrity & 0.078 & 0.063 & 0.667 & 0.32 & 63.2 \\
Pasting & 0.063 & 0.073 & 0.734 & 0.43 & 64.5 \\
temperature & & & & & \\
Amylose & 0.081 & 0.062 & 0.637 & 0.23 & 52.1 \\
Pasting viscosity & $0.023^{*}$ & 0.073 & 0.713 & 0.61 & 37.1 \\
Breakdown & $0.013^{*}$ & 0.053 & 0.792 & 0.57 & 28.7 \\
Consistency & 0.067 & 0.092 & 0.831 & 0.22 & 52.1 \\
Solubility & 0.086 & 0.073 & 0.832 & 0.33 & 65.1 \\
Swelling power & 0.067 & 0.089 & 0.561 & 0.42 & 43.2 \\
\hline Significant at & & & &
\end{tabular}

Significant at $\mathrm{p}<0.05$.

Table 2. Proximate analysis of transgenic starch

\begin{tabular}{lccc}
\hline Property & Transgenic & Non-transgenic & T-test (5\%) \\
\hline Dry matter (\%) & 34.2 & 34.4 & NS \\
Starch content (\%) & 77.5 & 83.9 & 5.30 \\
Ash (\%) & 2.7 & 2.8 & $\mathrm{NS}$ \\
Crude fibre (5\%) & 2.9 & 3.6 & 0.41 \\
Total sugar (\%) & 3.4 & 3.4 & $\mathrm{NS}$ \\
Pasting clarity (\%) & 65.7 & 58.7 & $\mathrm{NS}$ \\
Pasting temperature $\left({ }^{\circ} \mathrm{C}\right)$ & 64.3 & 67.5 & $\mathrm{NS}$ \\
Amylose $(\%)$ & 23.3 & 22.4 & $\mathrm{NS}$ \\
Pasting viscosity (m Pa s) & 621.0 & 783.2 & 20.37 \\
Breakdown (m Pa s) & 133.1 & 284.2 & 43.75 \\
Consistency (m Pa s) & 166.7 & 163.3 & $\mathrm{NS}$ \\
Solubility $(\%, \mathrm{db})$ & -136.3 & -143.2 & $\mathrm{NS}$ \\
Swelling power $(\%, \mathrm{~g} / \mathrm{g})$ & 37.9 & 41.7 & $\mathrm{NS}$ \\
\hline
\end{tabular}

\section{Discussion}

One of the goals of our Cassava Improvement Programme is to develop low-amylose $(<5 \%)$ cassava variety using transgenic approach. To achieve this goal, TME 12-2010 was created as an intermediate product in our effort to obtain low-amylose cassava varieties. TME 12-2010 is a transgenic plant derived from TME 12 which is 
constitutively expressing NPT-II and GUS marker genes. The T-DNA vector with pCsVMV-GUS and CaMV 35S-NPTII cassettes in transgenic cassava plants transcribed in opposite direction. The activity, level and pattern of expression of pCsVMV-GUS and CaMV 35S-NPTII in various organs and tissues of clonally propagated transgenic cassava plants have been described in detail by Opabode (2010). Additional report that the pCsVMV-GUS drives strong and constitutive expression in vascular tissues of petiole, stem and tuberous root and in leaf mesophyll tissues and vascular stele of roots of TME 12-2010 is provided by Ingelbrecht et al (2010). The successful creation of TME 12-2010 has provided some information that will guide our future effort at development of low-amylose TME 12 variety. The successful expression of the marker genes in TME 12-2010 established the fact that TME 12 can accept and express foreign genes and indeed agronomic traits. It further established that foreign DNA could be expressed in vital starch synthesis and storage cells and tissues. In addition, the integrity and stability of the promoter sequences used to drive the expression of the marker genes were established. The expression was strong and abundant and no case of gene silencing or promoter breakdown has been recorded after three cycles of vegetative propagation.

The inclusion of GUS and NPT-II marker genes as component of the transformation vectors for genetic modification of plant cells is predicated on the fact that the markers have no activity in plants. Consequently, markers' proteins make no interference in physiological, biochemical and morphological activities in transgenic plants. However report of recent times forced us to reconsider this position. The reported differential feeding responses of Colorado potato beetle larvae to transgenic potato plants containing NPT-II and GUS genes and non-transgenic potato plants by Lecardonnel et al. (2004) suggested that the two potatoes contain different constituents. In addition, transgenic crops have been reported to display slower growth compare with non-transgenic crops (Vinocur and Altiman, 2005). These reports informed our analysis of starches from TME 12-2010 (transgenic) and TME 12 (non-transgenic) to ascertain the impact of NPT-II and GUS genes on starch properties.

The dry matter content (33.2-35.7\%) of non-transgenic cassava tubers in this study agreed with the previous reports (14.3-47.9\%) on cassava landraces (Sanchez et al., 2009). Similarly, the ranges of ash content (2.6-2.8\%), crude fibre (2.8-3.7\%) and total sugars (3.2-3.6\%) observed in this are consistent with the previous reports for cassava landraces (Sanchez et al., 2009).

Several reasons could be adduced to lower starch content of TME 12-2010 (transgenic) than TME 12 (non-transgenic). First, growth of TME 12-2010 has been reported to be slower than TME 12 (Akinduro 2011, Yussuf, 2012). In the studies conducted on growth analysis of TME 12-2010, Akinduro (2010) \& Yussuf (2011) identified net assimilate rate and specific leaf weight as major different growth estimates between TME 12-2010 and TME 12. The two reports on the growth TME 12-2010 agreed with earlier report on slower growth of transgenic crops compare with non-transgenic one in the field (Vinocur \& Altiman, 2005). Second, although GUS gene has not been reported to interfere with photosynthetic activities in plants; its high activity along xylem, phloem and cambial tissues and photosynthetically active cells in leaf might affect photosynthesis in transgenic cassava. Third, the presence in and addition of NPT-II and GUS genes to cassava genome might affect the activities of photosynthetic enzymes, Photosystem I and II which have direct relationship with starch biosynthesis. Fourth, starch transport, degradation, storage and their enzymes might be affected by the presence and expression of the two marker genes. All the suggested reasons for the low starch content of transgenic cassava plants, except for growth analysis, need to be independently investigated and established. More importantly, in the present work, we could not establish which of the marker genes or their interaction actually exerted it effect on starch content and physicochemical properties of transgenic starch. To address this, there is a need to separately produced NPT-II and GUS cassava plants to ascertain the effect of each marker on plant activities. Similar reasons stated above suggested for significantly lower starch content in transgenic plant could also explain significant differences observed in crude fibre, pasting viscosity and breakdown value between transgenic and non-transgenic cassava plants.

\section{Acknowledgement}

The financial support of Obafemi Awolowo University's Research Committee and National Biotechnology Development Agency (NABDA), Abuja is acknowledged.

\section{References}

Akinduro, A. S. (2011). Morphological studies on transgenic cassava plant expressing marker genes. B. Agric. (Plant Science) Thesis (p. 22), Obafemi Awolowo University, Ile-Ife, Nigeria.

Association of Official Analytical Chemists (AOAC). (2000). Official Methods of Association of Official Analytical Chemist, Washington D.C. 
Benner, S. (2010). European Commission approves Amflora starch potato. Retrieved from http://www.basf.com/group/pressrelease/P-10-179.

Ceballos, H., Iglesias, C. A., Perez, J. C., \& Dixon, A. G. O. (2004). Cassava breeding: opportunities and challenges. Plant Mol. Biol., 56, 503-516. http:/dx.doi.10.1007/s11103-004-5010-5

Ceballos, H., Sanchez, T., Morante, N., Fregene, M., Dufour, D., Smith, A. M., ... Mestres, C. (2007). Discovery of an amylose-free starch mutant in cassava (Manihot esculenta Crantz). J. Agric. Food Chem., 55, 7469-7476. http://dx.doi.10.1021/jf070633y

Ceballos, H., Sanchez, T., Tofino, A. P., Rosero, E. A., Denyer, K., Smith, A. M., ... Fahy, B. (2008). Induction and identification of a small-granule, high-amylose mutant in cassava (Manihot esculenta Crantz). J. Agric. Food Chem., 56, 7215-7222. http://dx.doi.10.1021/jf800603p

Craig, J., Lloyd, J. R., Tomlinson, K., Barber, L., Edwards, A.,Wang, T. L., ...Smith, A. M. (1998). Mutations in the gene encoding starch synthase II profoundly alter amylopectin structure in pea embryos. Plant Cell, 10, 413-426. http:/dx.doi:10.1105/tpc.10.3.413

Davis, J. P., Supatcharee, N., Khandelwal, R. L., \& Chibbar, R. N. (2003). Synthesis of novel starches in planta: opportunities and challenges. Starch/Starke, 55, 107-120.

Defloor, I., Dehing, I. \& Delcour, J. A. (1998). Physico-chemical properties of cassava starch. Trop Sci. 31, 189-207. http://dx.doi.org/10.1002/(sici)1521-379x(199803)50

Dellaporta, S. L., Wood, J., \& Hicks, J. B. (1983). A plant DNA mini preparation: version II. Plant Mol Biol Rep, 1, 19-21. http://dx.doi.org/10.1007/bf02712670

Dubois, M., Gilles, K. A., Hamilton, J. K., Rebers, P. A., \& Smith, F. (1956). Colorimetric method for determination of sugars and related substances. Analy. Chem., 28, 350-356.

Gonzalez, A. E., Schopke, C., Taylor, N. J., Beachy, R. N., \& Fauquet, C. M. (1998). Regeneration of transgenic cassava plants (Manihot esculenta Crantz) through Agrobacterium-mediated transformation of embryogenic suspension cultures. Plant Cell Report, 17, 827-831. http://dx.doi.org/ 10.1007/s002990050492

Hankoua, B. B., Taylor, N. J., Ng, S. Y. C., Fawole, I., Puonti-Kaerlas, J., Padmanabhan, C., ... Fondong, V. N. (2006). Production of the first transgenic cassava in Africa via direct shoot organogenesis from friable embryogenic calli and germination of maturing somatic embryos. Afr. J. Biotech, 5, 1700-1712.

Ingelbrecht, I., Dixon, A .G. O., Raji, A., \& Opabode, J. T. (2010). Molecular enhancement of cassava (Manihot esculenta Crantz) for resistance to the cassava brown streak disease. Final Technical Report submitted to Rockefeller Foundation (p. 30). New York, USA.

Ihemere, U., Ariaz-Garzon, D., Lawrence, S., \& Sayre, R. (2006). Genetic modification of cassava for enhanced starch production. Plant Biotech J., 4, 453-465. http://dx.doi.10.1111/j.1467-7652.2006.00195.x

Jefferson, R. A. (1987). Assaying chimeric genes in plants. The UidA gene fusion system. Plant Mol Biol. Rep, 5, 387-405. http://dx.doi.org/ 10.1007/bf02667740

Joslyn, M. A. (1970). Methods in food analysis. 2nd edition. In M. A. Joslyn (Ed.), A series of monographs (pp. 552-557). New York: Academic Press.

Jorgensen, K., Bak, S., Busk, P. K., Sorensen, C., Olsen C. E., Puonti-Kaerlas, J., \& Moller, B. L. (2005). Cassava plants with a depleted cyanogenic glucoside content in leaves and tubers. Distribution of cyanogenic glucosides, their site of synthesis and transport, and blockage of biosynthesis by RNA interference technology. Plant Physiol, 139, 363-367. http://dx.doi.org/10.1104/pp.105.065904

Lecardonnel, B. R., Sorensen, C., \& Olsen, C. E. (2004). Observations on potato modified with NPT II-GUS gene. Transformation, 31,324-329

Opabode, J. T. (2010) Development of transgenic cassava plants with starch modification potential (p. 179). Ph. D Thesis, Obafemi Awolowo University, Il-Ife, Nigeria.

Raemakers, K., Schreuder, M., Suurs, L., Vincken, J. P., Jacobsen, E., \& Visser, R. G. F. (2005). Improved cassava starch by antisense inhibition of granule-bound starch synthase I. Mol Breed, 16, 163-172. http://dx.doi.org/10.1007/s11032-005-7874-8

Sanchez, T., Salcedo, E., Dufour, D., Morante, N., Debouck, D., \& Moreno, I. X. (2009). Screening of starch quality traits in cassava (Manihot esculenta Crantz). Starch/Starke, 61, 12-19. 
Schreuder, M. M., Raemakers, C. J. J. M., Jacobsen, E., \& Visser, R. G. F. (2001). Efficient production of transgenic plants by Agrobacterium-mediated transformation of cassava (Manihot esculenta Crantz). Euphytica, 120, 35-42. http://dx.doi.org/ 10.1023/a:1017530932536

Taylor, N., Chavarriaga, P., Raemakers, K., Siritunga, D., \& Zhang, P. (2004). Development and application of transgenic technologies in cassava. Plant Mol. Biol., 56, 671-688. http://dx.doi.org/10.1007/s11103-004-4872-x

Williams, P. C., Kuzina, F. D., \& Hlynka, I. (1970). A rapid colorimetric procedure for estimating the amylose content of starches and flours. Cereal chem., 47, 411.

Yussuf, A. M. (2012). Growth of transgenic cassava as influenced by cutting-type and planting orientation (p. 36). B. Agric. (Plant Science) Thesis, Obafemi Awolowo University, Ile-Ife, Nigeria.

Zhang, P., Jaynes, J., Potrykus, I., Gruissem, W., \& Pounti-Kaerlas, J. (2003). Transfer and expression of an artificial storage protein (ASP1) gene in cassava (Manihot esculenta Crantz). Tran Res, 12, 243-250. http://dx.doi.org/10.1023/a:1022918925882

Zhang, P., Vanderschuren, H., Futterer, J., \& Gruissem, W. (2005). Resistance to cassava mosaic disease in transgenic cassava expressing antisense RNAs targeting virus replication genes. Plant Biotech J., 3, 385-397. http://dx.doi.org/10.1111/j.1467-7652.2005.00132.x

Zhang, P., \& Pounti-Kaerlas, I. (2004). Regeneration of transgenic cassava from transformed embryogenic tissues. Methods Mol Biol, 286, 1025-1029. 